\title{
Antimicrobial activity of potato aspartic proteases (StAPs) involves membrane permeabilization
}

\begin{abstract}
Correspondence
María G. Guevara

gguevara@mdp.edu.ar
\end{abstract}

Received 27 December 2005

Revised 6 March 2006

Accepted 8 March 2006

\author{
Julieta R. Mendieta, Mariana R. Pagano, Fernando F. Muñoz, \\ Gustavo R. Daleo and María G. Guevara
}

Instituto de Investigaciones Biológicas, Facultad de Ciencias Exactas y Naturales, Universidad Nacional de Mar del Plata, CC 1247, Argentina

\begin{abstract}
Solanum tuberosum aspartic proteases (StAPs) with antimicrobial activity are induced after abiotic and biotic stress. In this study the ability of StAPs to produce a direct antimicrobial effect was investigated. Viability assays demonstrated that StAPs are able to kill spores of Fusarium solani and Phytophthora infestans in a dose-dependent manner. Localization experiments with FITC-labelled StAPs proved that the proteins interact directly with the surface of spores and hyphae of $F$. solani and $P$. infestans. Moreover, incubation of spores and hyphae with StAPs resulted in membrane permeabilization, as shown by the uptake of the fluorescent dye SYTOX Green. It is concluded that the antimicrobial effect of StAPs against $F$. solani and $P$. infestans is caused by a direct interaction with the microbial surfaces followed by membrane permeabilization.
\end{abstract}

\section{INTRODUCTION}

Plants, as well as animals, can defend themselves against pathogenic microbes via cationic antimicrobial proteins and peptides, which can kill micro-organisms without any harmful effect on the host (Hancock \& Lehrer 1998; Levy, 2004; Brogden, 2005).

Several plant proteins capable of inhibiting fungal growth in vitro have been isolated and characterized. Among these proteins, called antifungal proteins (AFPs), glucanases and chitinases (Mauch et al., 1988), thaumatin-like proteins (Hejgaard et al., 1992; Vigers et al., 1991; Woloshuk et al., 1991), several families of basic-cysteine-rich peptides (Broekaert et al., 1997), chitin-binding proteins (Raikhel et al., 1993), ribosome-inactivating proteins (Leah et al., 1991), aspartic proteinases (Guevara et al., 2002, 2004) and proteinase inhibitors (Terras et al., 1993) have been found. AFPs may be part of the preformed defence barriers or may be induced upon perception of a micro-organism. There is evidence that these proteins may have a direct antimicrobial activity in vivo. In particular, previous studies have shown enhanced resistance to microbial pathogens by transgenic plants overexpressing some of these antimicrobial proteins (Dixon et al., 1996).

Aspartic proteases (EC 3.4.23) (AP) are a class of widely distributed proteases present in animals, microbes, viruses and plants (Davies, 1990; Rawlings \& Barrett, 1995). Biological functions of plant APs have not been characterized as well as those of their mammalian, microbial or viral

Abbreviations: AP, aspartic protease; StAP, Solanum tuberosum aspartic protease; DAB, 3,3'-diaminobenzidine. counterparts (Davies, 1990; Rawlings \& Barrett, 1995; Mutlu \& Gal, 1999).

Previously, we reported the first evidence of the bifunctional activity - proteolytic and antimicrobial - of plant APs (Guevara et al., 2002, 2004). We have identified three potato (Solanum tuberosum) aspartic proteases, one from tubers (StAP1) (Guevara et al., 1999) and two from leaves (StAP2 and StAP3) (Guevara et al., 2001). Two of these isoforms, StAP1 and StAP3, have been purified and characterized. Both proteins are induced by both abiotic and biotic stress (Guevara et al., 2001, 2002), have an extracellular localization and produce a direct inhibitory effect in vitro on the germination of cysts of Phytophthora infestans and conidia of Fusarium solani (Guevara et al., 2002, 2004).

The aim of this work was to determine whether the StAPs produce a cytotoxic effect on fungal cells mediated by a direct interaction with fungal surface structures. The results presented here provide insight into the antimicrobial mode of action of StAPs.

\section{METHODS}

Biological materials. Potato tubers (Solanum tuberosum cv. Pampeana) were provided by the Balcarce Experimental Station of the Instituto Nacional de Tecnologia Agropecuaria (INTA), Argentina. S. tuberosum cv. Pampeana INTA (MPI 59.789/12 $\times$ Huinkul MAG) is a cultivar from the Argentine Breeding Programme (INTA-Balcarce).

Fusarium solani f. sp. eumartii, isolate 3122 (EEA-INTA, Balcarce, Argentina) was grown at $25^{\circ} \mathrm{C}$ on potato dextrose (glucose) agar (PDA) plates supplemented with $100 \mu \mathrm{g}$ ampicillin $\mathrm{ml}^{-1}$, and spores were collected from 8-day-old cultures by suspension in sterile water. 
Phytophthora infestans, mating type $\mathrm{A} 2$, was grown on $\mathrm{V}_{8}$-agar medium and on potato tuber slices. Mycelia were harvested in sterile water and stimulated to release zoospores by incubation for $2-3 \mathrm{~h}$ at $4{ }^{\circ} \mathrm{C}$. After filtration through muslin, the resultant suspension was observed by light microscopy for quantification of zoospores.

Protein purification. Sterile disks (10 mm diameter, $2 \mathrm{~mm}$ thick) of potato tuber were prepared, washed extensively and suspended in sterile water ( 15 disks in $23 \mathrm{ml}$ water) and aerated for $24 \mathrm{~h}$ at $25^{\circ} \mathrm{C}$ in an orbital shaker at 60 cycles $\mathrm{min}^{-1}$. StAP1 was purified from tubers using the protocol previously described by Guevara et al. (1999).

Potato leaves were detached and placed at $18{ }^{\circ} \mathrm{C}$ in a moist chamber. StAP3 was purified from leaves using the protocol previously described by Guevara et al. (2001).

The purity of proteins was checked by SDS-PAGE using $15 \%$ acrylamide gels (Laemmli, 1970). Gels were stained with silver nitrate (Oakley et al., 1980).

Analytical procedures and measurement of enzymic activities. Protein concentration was measured by the bicinchoninic acid method (Smith et al., 1985), using BSA as standard.

Proteolytic activity was measured with haemoglobin as substrate according to the method described by Anson (1979). One unit (U) is defined as the activity required to produce an increase in absorbance of $0 \cdot 1$ at $750 \mathrm{~nm}$, in $1 \mathrm{~h}$ at $37^{\circ} \mathrm{C}$.

Determination of the fungicidal properties of StAPs. Test samples containing $30 \mu \mathrm{l}$ of the spore suspension $\left(2 \times 10^{4}\right.$ spores $\left.\mathrm{ml}^{-1}\right)$ were incubated with different amounts $(0 \cdot 3,0 \cdot 75,1 \cdot 2,1 \cdot 9$, $2 \cdot 5,3 \cdot 75,6 \cdot 25$ or $10 \mu \mathrm{M})$ of either StAP1, StAP3 or $10 \mu \mathrm{M}$ pepsin, a mammalian aspartic protease (EC 3.4.23.1) (Sigma) in a final volume of $50 \mu \mathrm{l}$. Samples were mixed, incubated for 15,30 and $60 \mathrm{~min}$ at $25^{\circ} \mathrm{C}$ and then spread on PDA plates. After 3 days at $25^{\circ} \mathrm{C}$, colonies were counted. Bioassays were performed three times and the mean number of c.f.u. was calculated for each treatment (De Luca et al., 1999). The $\mathrm{IC}_{50}$ (concentration needed to reduce spore viability by $50 \%)$ was determined.

Detection of $\mathbf{H}_{\mathbf{2}} \mathrm{O}_{\mathbf{2}}$. Detection of $\mathrm{H}_{2} \mathrm{O}_{2}$ in situ was performed by an endogenous peroxidase-dependent histochemical staining procedure using 3,3'-diaminobenzidine (DAB) (Sigma), as described by Thordal-Christensen et al. (1997) with minor modifications. Briefly, the spores (final concentration $2.7 \times 10^{6}$ spores $\mathrm{ml}^{-1}$ ) were incubated with water (control) or different amounts of StAP1, StAP3 or pepsin $(1 \cdot 2,1.85$ or $3.75 \mu \mathrm{M})$ in the presence of $0.5 \mathrm{mg} \mathrm{DAB} \mathrm{ml} \mathrm{m}^{-1}$ for $1 \mathrm{~h}$ and observed microscopically after previous rinsing. This time was necessary to ensure $\mathrm{DAB}$ uptake by the fungal cells. DAB polymerizes instantly and locally as soon as it comes into contact with $\mathrm{H}_{2} \mathrm{O}_{2}$ in the presence of peroxidase.

Protease labelling. Purified StAP1, StAP3 and pepsin (1 mg) were labelled with FITC, Isomer I, using the FluoroTag FITC Conjugation kit (Sigma). Labelled proteases were separated from unlabelled protease and free label according to the procedure recommended by the manufacturer. Assays using haemoglobin as substrate were performed in order to check the proteolytic activity of labelled StAPs. No changes were observed in the specific activity of FITC-labelled StAPs as compared to unlabelled StAPs.

Binding of StAPs to the surface of spores and hyphae. F. solani spores $\left(2 \cdot 7 \times 10^{6}\right.$ spores $\left.\mathrm{ml}^{-1}\right)$ were incubated with different concentrations of labelled-StAPs $(0.3,0.75,1.2,1.9,2.5$ and $3 \cdot 75 \mu \mathrm{M})$ for three different lengths of time (15 min, $30 \mathrm{~min}$ and $2 \mathrm{~h})$. After $16 \mathrm{~h}$ incubation of spores at $25^{\circ} \mathrm{C}$ and $100 \%$ relative humidity, growing hyphae were treated with FITC-labelled StAPs.
Similarly, $P$. infestans cysts $\left(2 \times 10^{5}\right.$ cysts $\left.\mathrm{ml}^{-1}\right)$ were incubated with different amounts of FITC-labelled-StAPs (from $0 \cdot 1 \mathrm{nM}$ to $2 \mu \mathrm{M}$ ) for $16 \mathrm{~h}$. After incubation, the number of fluorescent spores or hyphae was evaluated. Controls were performed replacing the protease solutions with $10 \mu \mathrm{M}$ of pepsin or water. The binding of StAPs to the surface of spores and hyphae was examined with a Nikon Eclipse E200 fluorescence microscope equipped with a B-2 filter set (Nikon) for fluorescein detection. A quantitative test was performed by counting the fluorescent and non-fluorescent spores on a Neubauer camera. The results from three independent experiments were analysed to calculate the percentage fluorescence.

Assay for antimicrobial activity. To assay the effect of StAPs on the germination of cysts of $P$. infestans and spores of $F$. solani, in vitro bioassays were performed as described by Guevara et al. (2002). The buffer used for the incubation of F. solani spores was supplemented with the amount of $\mathrm{NaCl}$ needed to reach the final concentrations indicated $(75,150$ or $300 \mathrm{mM})$. After incubation in the same conditions of time and dose as described above, the slides were evaluated for inhibition of germination under a light microscope by counting on a Neubauer camera. Three independent experiments were performed.

Assay for fungal membrane permeabilization. F. solani spores and mycelia were incubated overnight at $25^{\circ} \mathrm{C}$ with water (controls) or exposed to different amounts of StAP1, StAP3 or pepsin $(0 \cdot 3$, $0 \cdot 75,1 \cdot 2,1 \cdot 9,2 \cdot 5,3 \cdot 75,6 \cdot 25$ or $10 \mu \mathrm{M})$ as described by Guevara et al. (2002).

$P$. infestans cysts were incubated for $16 \mathrm{~h}$ at $18{ }^{\circ} \mathrm{C}$ with water (controls) or exposed to different amounts of StAP1 and StAP3 (from $0 \cdot 1 \mathrm{nM}$ to $2 \mu \mathrm{M}$ ) or pepsin, according to Guevara et al. (2002).

SYTOX Green probe (Molecular Probes) was added at a final concentration of $1 \mu \mathrm{M}$ and qualitative detection of SYTOX Green uptake was done, after 30,60 and $90 \mathrm{~min}$ incubation for F. solani or $30 \mathrm{~min}$ for $P$. infestans, with a Nikon Eclipse E200 fluorescence microscope equipped with a B-2A Fluorescein filter set. Positive controls included spores and cysts treated with $0 \cdot 5 \%(\mathrm{w} / \mathrm{w})$ Triton X-100. Fluorescence was measured using a FluoresKan Ascent (Thermo Electron Corp.) fluorescence measurement system, at an excitation wavelength of $480 \mathrm{~nm}$ and an emission wavelength of $530 \mathrm{~nm}$. Fluorescence values were corrected by subtracting the fluorescence value of a buffer incubated with SYTOX Green.

Statistical analysis. To determine a possible correlation between FITC-StAP binding, antifungal activity and membrane permeabilization effect, $P$ values of the corresponding data were calculated by analysis of variance using Microsoft Excel.

\section{RESULTS}

\section{Fungicidal effect of StAPs}

In initial dose-response experiments, $F$. solani spores were incubated with different amounts of StAPs or pepsin for 15, 30 and $60 \mathrm{~min}$ at $25^{\circ} \mathrm{C}$. After this treatment the spore solutions were plated on PDA medium and incubated for 3 days to verify the presence of fungal colonies. As shown in Fig. 1, 15 min incubation with either StAP was sufficient to reduce the viability of spores in a dose-dependent manner. StAP3 had an $\mathrm{IC}_{50}$ almost twofold lower $(0.54 \mu \mathrm{M})$ than that of StAP1 $(0.93 \mu \mathrm{M})$ after 15 min incubation (Fig. 1) as well as after 30 and 60 min (results not shown). 


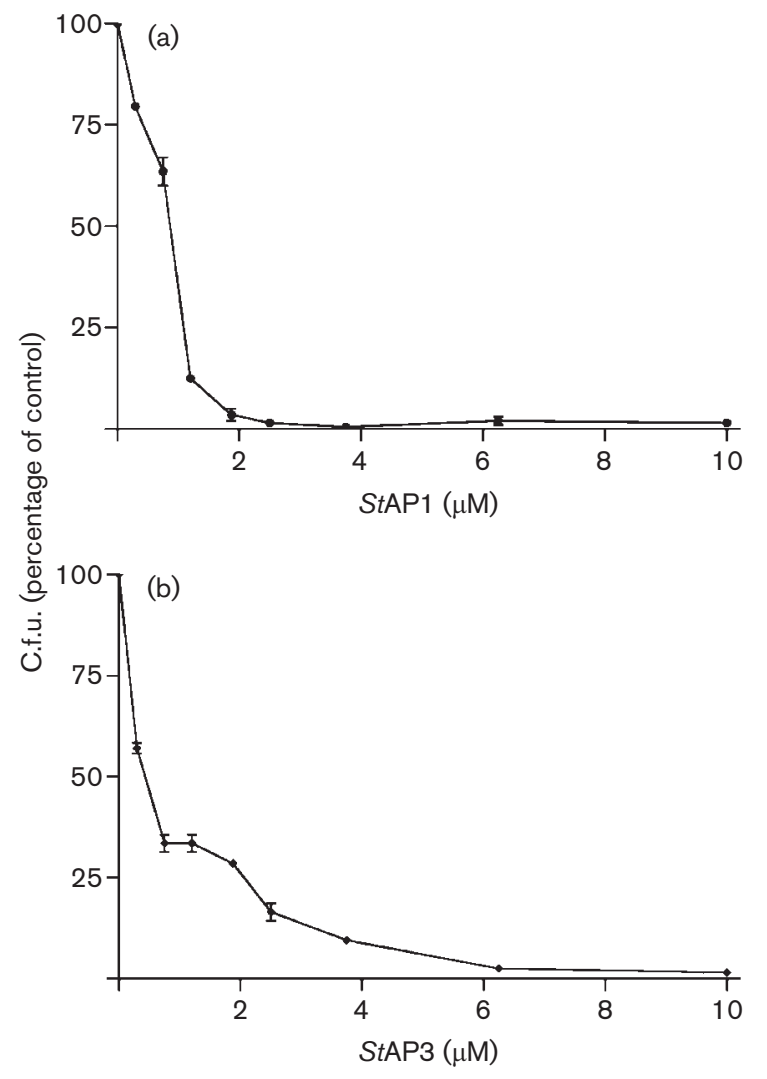

Fig. 1. Lethal effect of StAPs on F. solani spores. The spores were incubated for $15 \mathrm{~min}$ at $25^{\circ} \mathrm{C}$ with different amounts $(0 \cdot 3,0 \cdot 75,1 \cdot 2,1 \cdot 9,2 \cdot 5,3 \cdot 75,6 \cdot 25$ or $10 \mu \mathrm{M})$ of (a) StAP1 or (b) StAP3 or with $10 \mu \mathrm{M}$ pepsin and then spread on PDA plates. Colonies were counted after 3 days. The number of colonies from control spores treated with water was taken as $100 \%$. Means of three experiments; error bars represent SD.

The viability of spores incubated in the presence of different amounts of pepsin was not affected.

\section{StAPs induce ROS production}

The capacity of StAPs to generate oxygen reactive species (ROS) in spores was analysed. Fungal spores were treated with different concentrations of StAP1 and StAP3 in the presence of DAB, a reagent that can enter into cells and produce an insoluble coloured complex in contact with $\mathrm{H}_{2} \mathrm{O}_{2}$ (Thordal-Christensen et al., 1997). The micrographs in Fig. 2 show that in the presence of StAPs, spores developed a strong reddish-brown pellet (Fig. 2a), clearly indicating the existence of endogenous ROS in StAP-treated fungal cells. No ROS generation was detected when pepsin was used in the assays (Fig. 2a).

The quantification of this effect revealed that the generation of $\mathrm{H}_{2} \mathrm{O}_{2}$ increased as the StAP1 and StAP3 dose rose (Fig. 2b).

\section{Interaction of StAPs with the surface of spores and hyphae of $\boldsymbol{F}$. solani}

To determine whether the fungicidal effect of StAPs is related to direct or indirect interaction with fungal cells, different amounts of FITC-StAPs were incubated with spores and hyphae of F. solani. The results showed that StAP1 and StAP3 were able to bind to the spore surface at all concentrations assayed in a dose-dependent manner (Fig. 3c, d). For both StAPs, the percentage of fluorescent spores increased in parallel with the percentage inhibition of germination. An amount 1.5-fold lower of StAP3, as compared to StAP1, was needed to obtain $50 \%$ of fluorescent spores. Fluorescent hyphae were observed at all concentrations of StAPs assayed (Fig. 3b). The specificity of the binding was studied by incubating spores with FITC-labelled pepsin. No fluorescent spores or hyphae were observed with this enzyme even at a concentration of 3.75 $\mu \mathrm{M}$ (Fig. 3a, b).

The capacity of StAPs to bind to spores of F. solani was independent of the time of incubation at all StAP concentrations assayed: the percentage of fluorescent spores was the same at all times of incubation $(15,30$ or $120 \mathrm{~min}$ ) (results not shown). These results suggest that the interaction between StAPs and fungal structures is direct and stable.

\section{StAPs induce membrane permeabilization in F. solani}

To check whether StAPs have an effect on fungal membranes, we used an assay based on the uptake of the fluorogenic dye SYTOX Green (Thevissen et al., 1999). This reagent only penetrates cells that have damaged plasma membranes and fluoresces upon binding to DNA. F. solani spores and hyphae were incubated with $0 \cdot 3,0 \cdot 75,1 \cdot 2,1 \cdot 9$, $2 \cdot 5,3 \cdot 75,6 \cdot 25$ or $10 \mu \mathrm{M}$ StAP1 or StAP3 or $10 \mu \mathrm{M}$ pepsin. These assays were performed in the same conditions as reported for antifungal activity (Guevara et al., 2002). SYTOX Green was then added to evaluate membrane integrity.

Fig. 4(a) and (b) show the effect of StAPs on SYTOX Green uptake by F. solani spores and hyphae respectively, observed by fluorescence microscopy. No fluorescent spores or hyphae were observed in the presence of pepsin or buffer. The fluorescent probe was incorporated into the fungal spores and hyphae in a dose-dependent manner in the presence of either StAP (Fig. 4c, d). These results indicate that StAP1 and StAP3 are able to induce membrane permeabilization in spores and hyphae of $F$. solani. The percentage fluorescence values increased between 30 and $60 \mathrm{~min}$ after incubation of spores with different amounts $(0-6 \cdot 25 \mu \mathrm{M})$ of StAP1 (Fig. 4c). However, no significant increases in the percentage fluorescence with time were observed when different amounts of StAP3 were used (Fig. 4d). No SYTOX Green uptake was detected at 
(a)

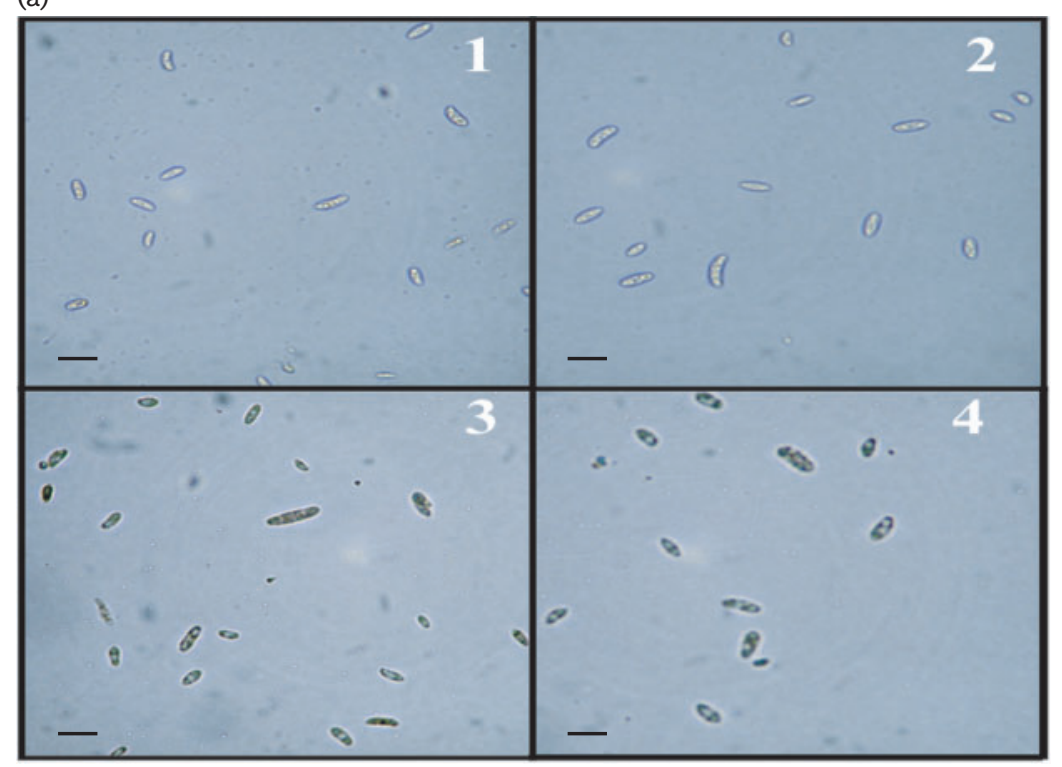

(b)

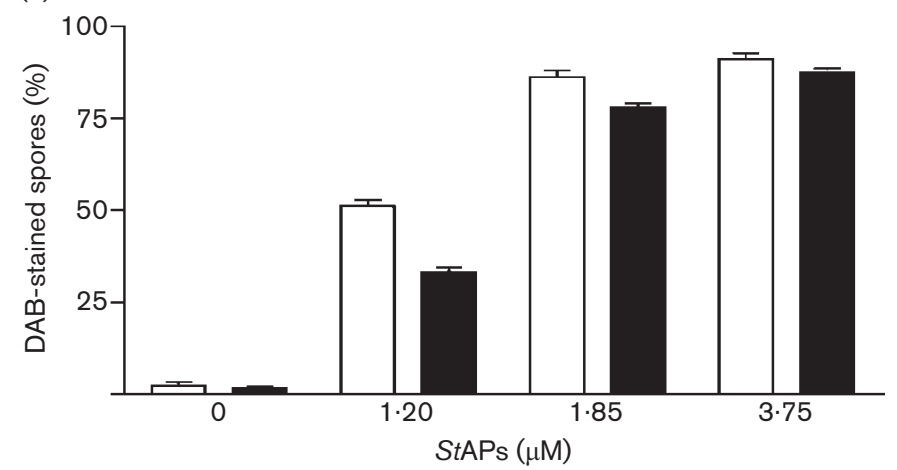

Fig. 2. Detection of $\mathrm{H}_{2} \mathrm{O}_{2}$ in spores of $F$. solani. (a) Spores stained with $\mathrm{DAB}$ in the presence of water $\left(a_{1}\right), 3 \cdot 75 \mu \mathrm{M}$ of pepsin $\left(a_{2}\right), 3 \cdot 75 \mu \mathrm{M}$ of StAP1 $\left(a_{3}\right)$ or $3.75 \mu \mathrm{M}$ of StAP3 $\left(a_{4}\right)$. Uptake of DAB is confirmed by the dark staining (reddish-brown) reaction in the spores. Bars, $15 \mu \mathrm{m}$. (b) Percentage of DAB-stained spores as a function of StAP1 (white bars) or StAP3 (black bars) concentration. Means of three experiments; error bars represent SD. concentrations below $0 \cdot 3 \mu \mathrm{M}$ of StAP1 and $0 \cdot 25 \mu \mathrm{M}$ of StAP3.

\section{lonic strength sensitivity of the antimicrobial activity of StAPs}

Ionic strength sensitivity of antimicrobial activity has been reported for antimicrobial proteins and peptides (Bruhn et al., 2003; Theis et al., 2003). Table 1 shows the effect of increasing the ionic strength on the antimicrobial activity of StAPs. The cytotoxic activity of both StAPs was unaffected by the addition of $75 \mathrm{mM} \mathrm{NaCl}$. At higher $\mathrm{NaCl}$ concentrations, the cytotoxic activity of both StAPs decreased.

\section{Effect of StAPs on P. infestans}

To study the antimicrobial activity of StAPs on another potato pathogen, $P$. infestans, we analysed the inhibition of germination, surface binding and membrane permeabilization of $P$. infestans cysts in the presence of different amounts of StAPs and pepsin. As shown in Fig. 5, the concentration of StAP1 ( $5 \mathrm{nM})$ needed to inhibit germination by $50 \%$ was almost 70 -fold lower than that of StAP3 (370 nM) (Fig. 5a, b). Also, both StAPs were able to bind to the fungal surface (Fig. $5 \mathrm{c}, \mathrm{d}$ ) and to permeabilize cell membranes (Fig. 5e, f). When pepsin was incubated with cysts of $P$. infestans, inhibition of germination, protein binding to surfaces and membrane permeabilization were not observed.

\section{DISCUSSION}

Antimicrobial proteins and peptides are an important component of the natural defences of most living organisms against invading pathogens and are found in a wide range of eukaryotic organisms, from humans to plants (Ganz, 2003; Lehrer, 2004; Zasloff, 2002; Brogden et al., 2003; Vizioli \& Salzet, 2002). Plant APs have been implicated in protein processing and/or degradation in different plant organs, as well as in plant senescence, stress responses, programmed cell death and reproduction (Mutlu \& Gal, 1999; Davies, 1990; Rawlings \& Barrett, 1995; Simões \& Faro, 2004; Ge et al., 2005). StAP1 and StAP3 have been associated with the plant defence mechanism in S. tuberosum, and their 
(a)

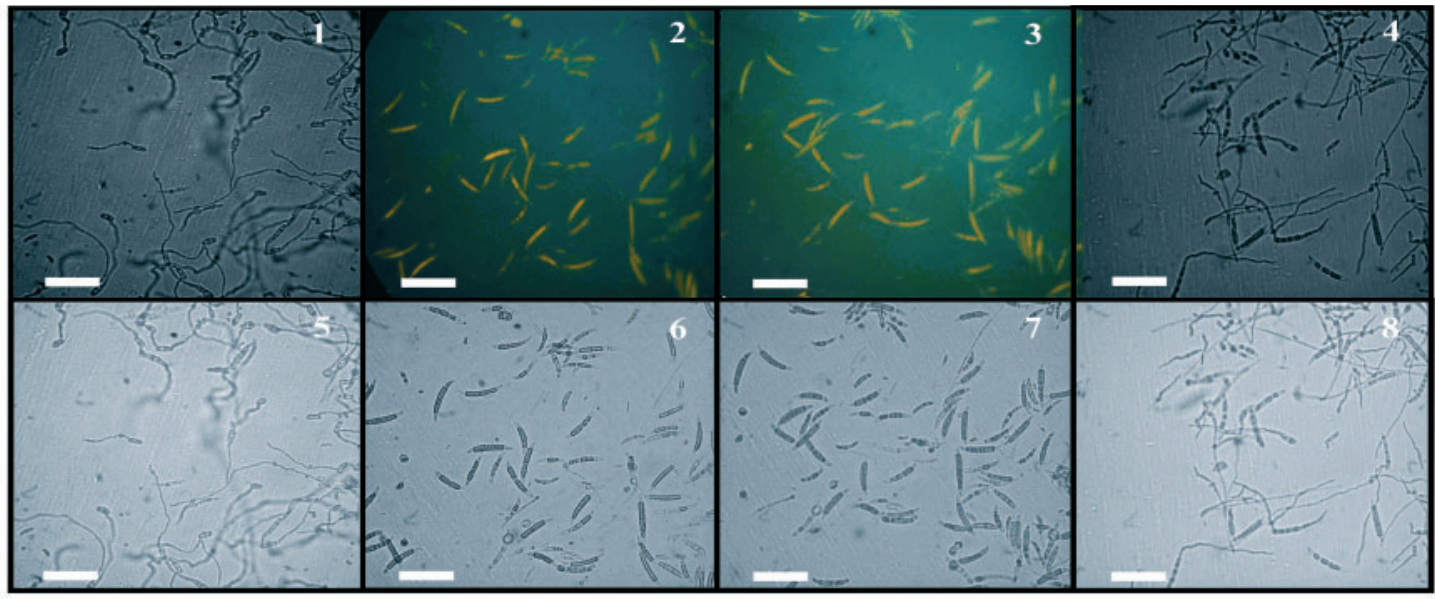

(b)

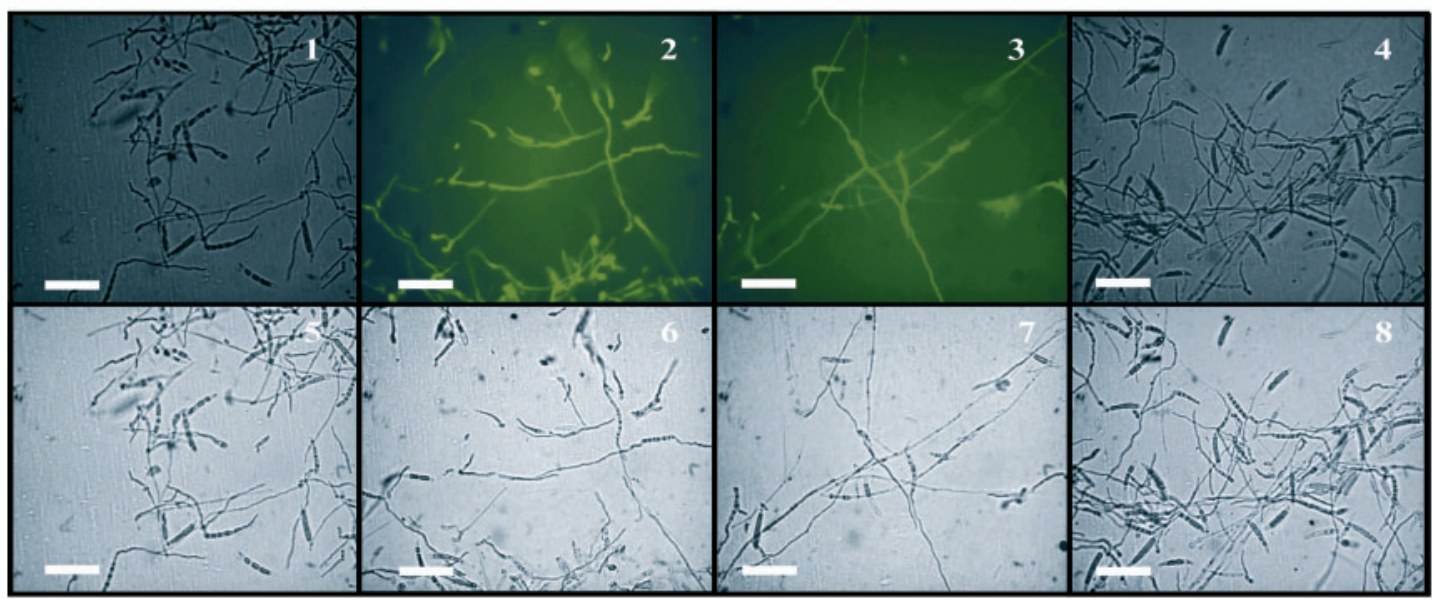

(c)

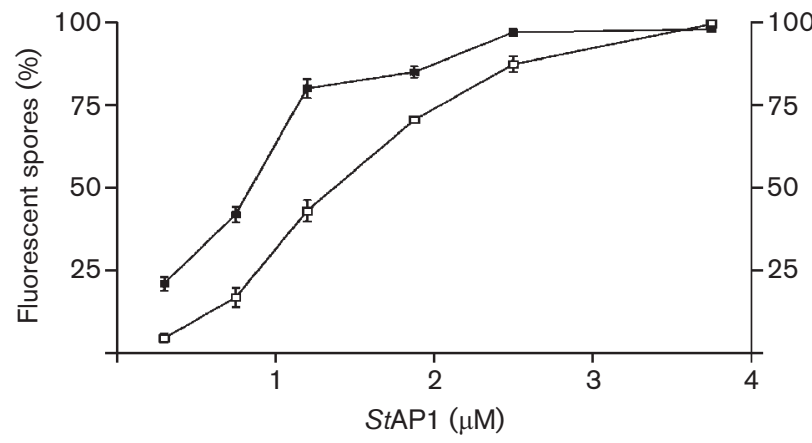

(d)

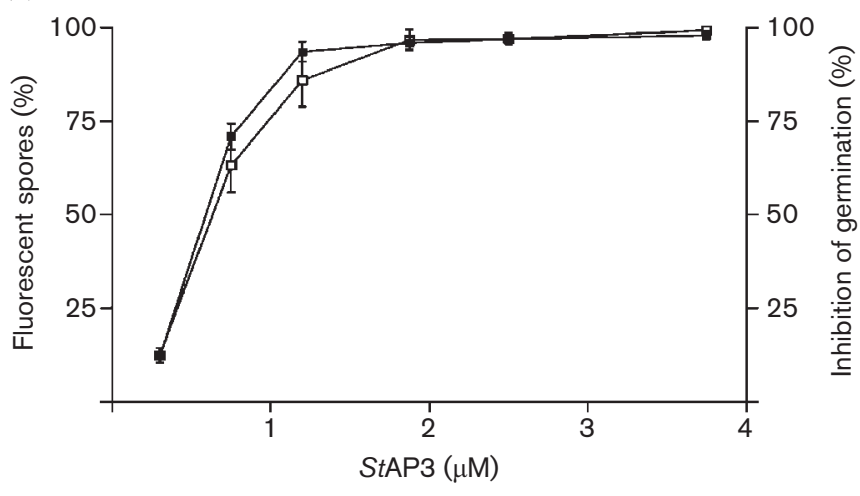

Fig. 3. Ability of StAPs to bind to fungal surface structures. $(a, b)$ Spores (a) and hyphae (b) of $F$. solani were incubated with $3.75 \mu \mathrm{M}$ of FITC-labelled StAPs. After $16 \mathrm{~h}$ incubation, the labelled protein was detected by fluorescence microscopy. Panels 1, 2, 3 and 4, fluorescence microscopy; panels 5, 6, 7 and 8, light-field microscopy. Panels 1 and 5, control; panels 2 and 6, $3 \cdot 75 \mu \mathrm{M}$ of FITC-labelled StAP1; panels 3 and 7, 3.75 $\mu \mathrm{M}$ of FITC-labelled StAP3; panels 4 and $8,3 \cdot 75 \mu \mathrm{M}$ of FITC-labelled pepsin. Bars, $15 \mu \mathrm{m}$. (c, d) Percentage of fluorescent spores ( $\boldsymbol{\square}$ ) and percentage inhibition of spore germination $(\square)$ after incubation with StAP1 (c) or StAP3 (d). The number of spores treated with $3.75 \mu \mathrm{M}$ of FITC-labelled-StAP was taken as $100 \%$. Means of three experiments; error bars represent SD.

antimicrobial activity, in vitro, against the potato pathogens $F$. solani and $P$. infestans has been reported (Guevara et al., 2002, 2004). However the mode of action of these enzymes is unknown.
The first point analysed in this work was whether the antimicrobial activity of StAPs involved just the arrest of mycelial growth or the killing of the microbial spores. The results obtained show that the viability of the spores of $F$. 
(a)

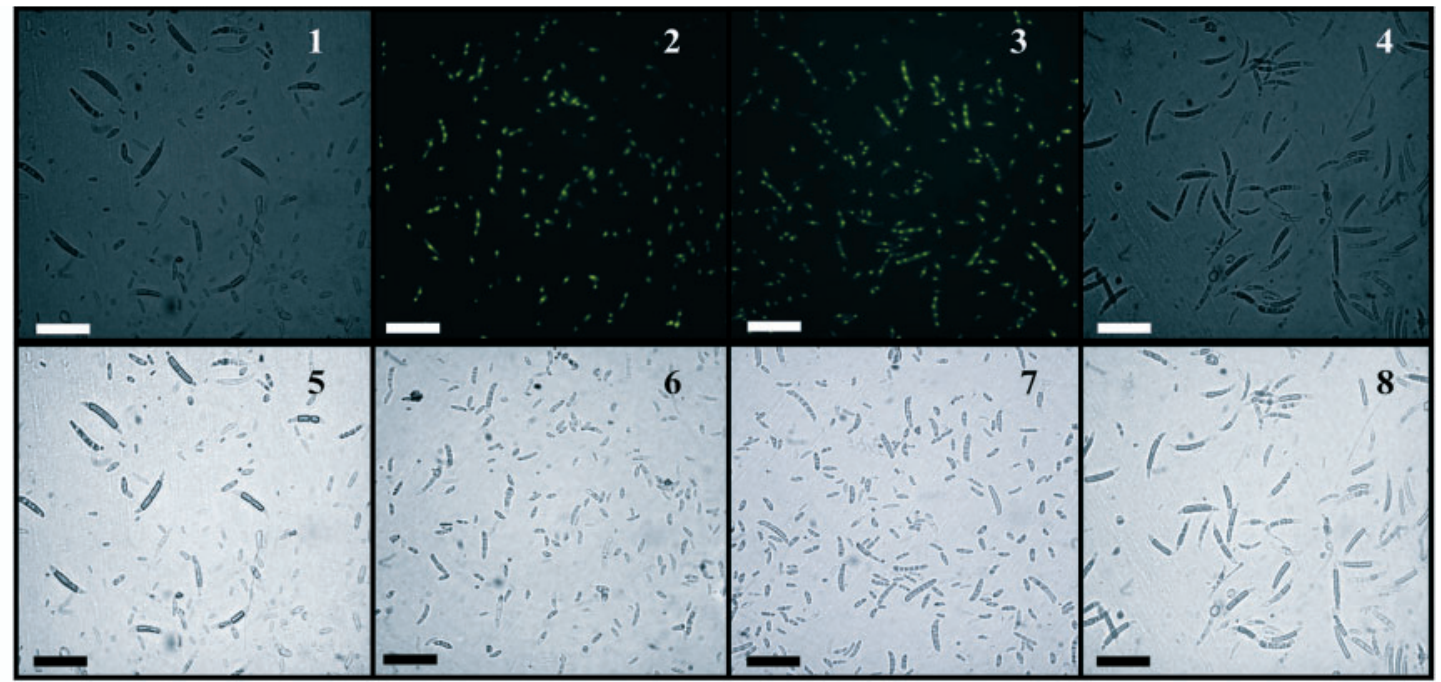

(b)

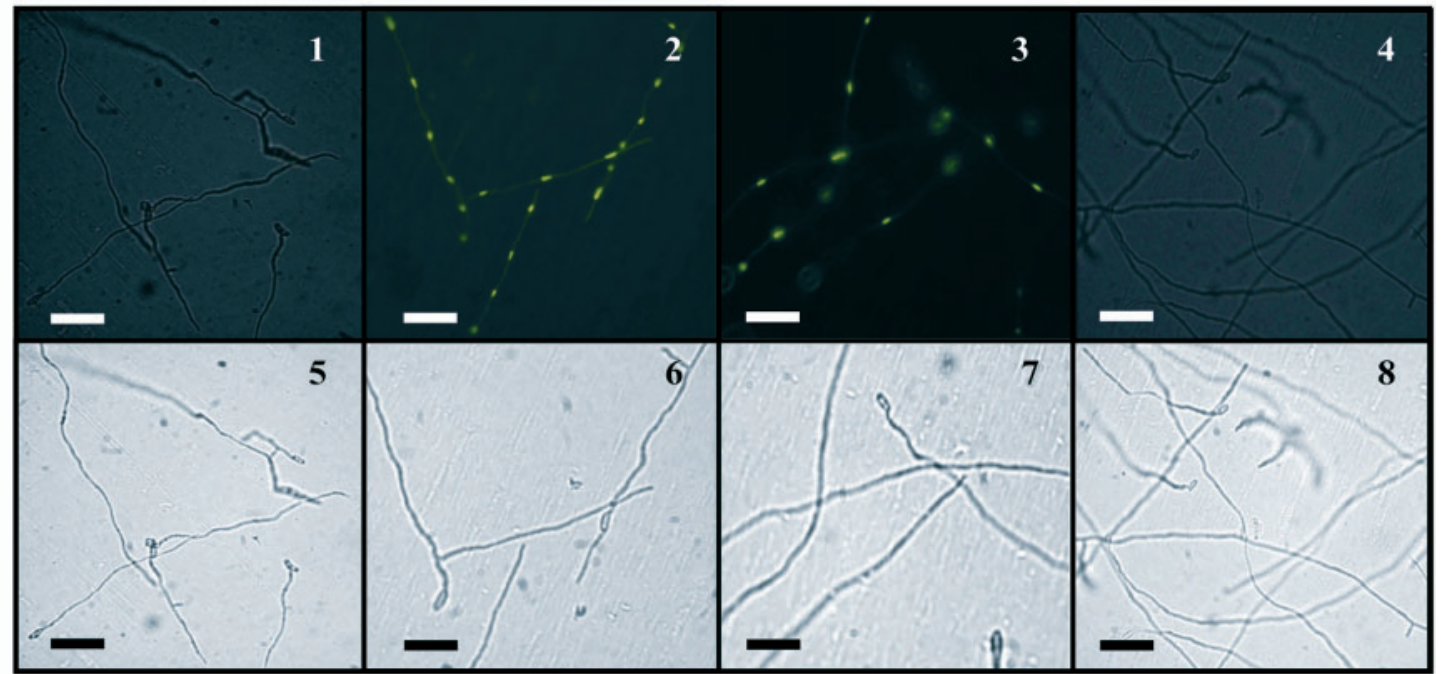

(c)

(d)
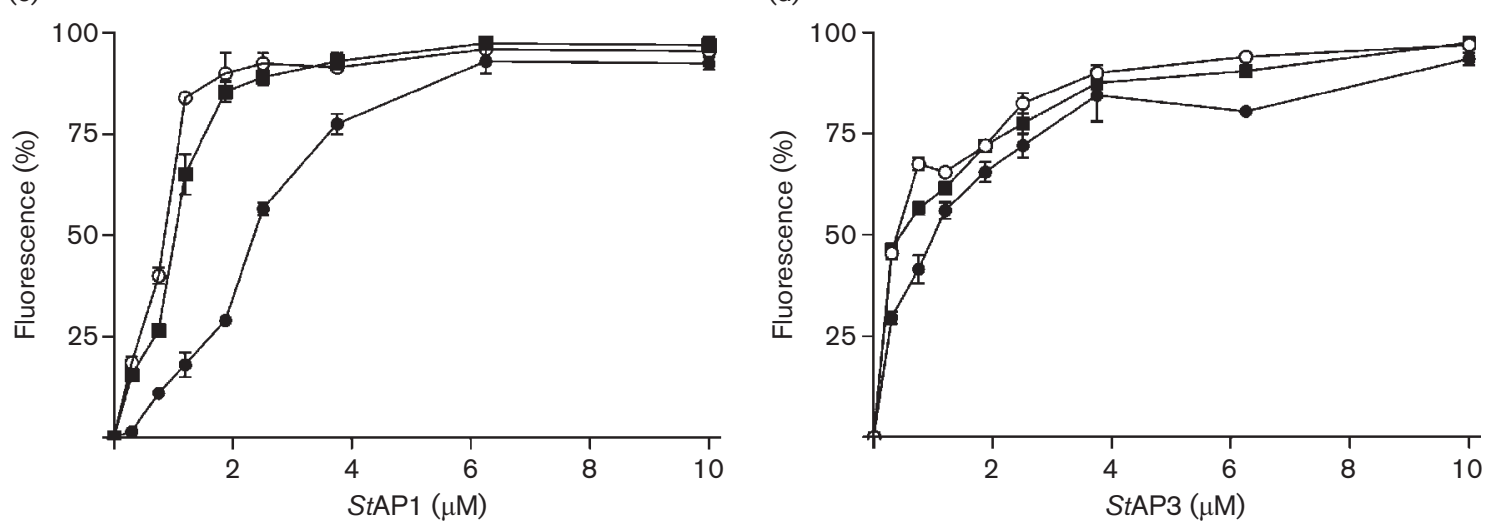

Fig. 4. Membrane permeabilization induced in spores and hyphae of $F$. solani after incubating with StAPs, detected by StAPinduced SYTOX Green uptake. (a, b) Spores (a) and hyphae (b) of $F$. solani were incubated with 3.75 $\mu \mathrm{M}$ of StAPs in the presence of $1 \mu \mathrm{M}$ SYTOX Green. After $30 \mathrm{~min}$ incubation, the fluorescence was detected by fluorescence microscopy. Panels 1, 2, 3 and 4, fluorescence microscopy; panels 5, 6, 7 and 8, light-field microscopy; panels 1 and 5: control. Panels 2 and 6, 3.75 $\mu \mathrm{M}$ of StAP1; panels 3 and 7, 3.75 $\mu \mathrm{M}$ of StAP3; panels 4 and 8, 3.75 $\mu \mathrm{M}$ of pepsin. Bars, $15 \mu \mathrm{m}$. (c, d) Spores of $F$. solani were incubated with different amounts of StAP1 (c) or StAP3 (d) for $30(\bullet), 60(\square)$ or $90(\square)$ min in the presence of $1 \mu \mathrm{M}$ SYTOX Green. Data are means \pm SD from triplicate measurements. The number of fluorescent spores treated with $0.5 \%(\mathrm{w} / \mathrm{w})$ of Triton $\mathrm{X}-100$ was taken as $100 \%$. 
solani was significantly reduced by both StAPs in a dosedependent manner, clearly indicating that these proteases possess fungicidal (not fungistatic) properties. The lethal doses necessary to kill $50 \%$ of the spores of F. solani $(2 \cdot 5 \mu \mathrm{M}$ StAP1 and $7 \cdot 75 \mu \mathrm{M}$ StAP3) are in the same magnitude order as values reported for this parameter for snakin-1 and 2, two potato antimicrobial peptides (Berrocal-Lobo et al., 2002;
Segura et al., 1999). On the other hand, the concentrations of StAPs needed to kill $50 \%$ of cysts of P. infestans ( $5 \mathrm{nM}$ StAP1 and $370 \mathrm{nM}$ StAP3) were significantly lower than those previously reported for potato proteins active against $P$. infestans (Niderman et al., 1995; Liu et al., 1994; Woloshuk et al., 1991). All these assays showed that the antimicrobial effect of StAPs is higher towards P. infestans
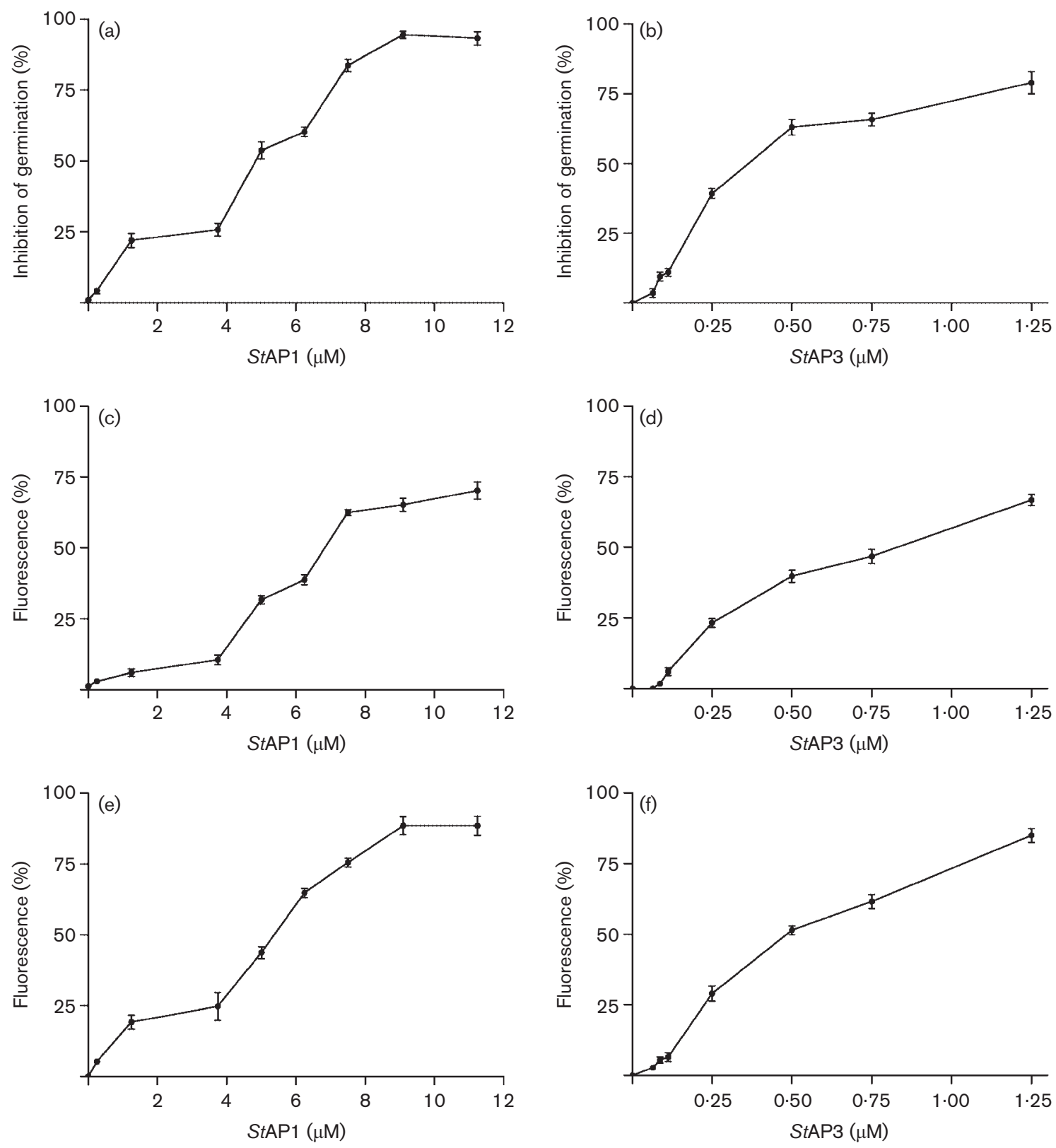

Fig. 5. Effect of StAPs on cysts of $P$. infestans. $(a, b)$ Inhibition of germination was evaluated after incubating cysts with different amounts of StAP1 (a) or StAP3 (b). Capacity of StAPs to bind to the fungal surface was evaluated after incubating cysts with different amounts of FITC-labelled StAP1 (c) or FITC-labelled StAP3 (d). The number of cysts treated with 20 nM of FITC-labelled StAP1 and $3 \mu \mathrm{M}$ of FITC-labelled StAP3 was taken as $100 \%$. (e, f) Ability of StAPs to permeabilize cyst membranes was analysed by incubating cysts with different amounts of StAP1 (e) or StAP3 (f) for 30 min in the presence of $1 \mu \mathrm{M}$ SYTOX Green. Data are means \pm SD of triplicate measurements. The number of fluorescent spores treated with $0.5 \%$ (w/w) of Triton was taken as $100 \%$. 
Table 1. Influence of $\mathrm{NaCl}$ concentration on the fungicidal activity of StAPs towards F. solani

The fungicidal activity according to the standard assay is normalized to $100 \%$. The calculation of the residual activity (\%) is based on the $\mathrm{IC}_{50}$ values (concentration needed to reduce spore viability by $50 \%$ ), because $\mathrm{IC}_{100}$ values were not reached upon addition of higher concentrations of $\mathrm{NaCl}$. The results are means \pm SD $(n=3)$.

\begin{tabular}{|lcc|}
\hline \multirow{2}{*}{$\mathrm{NaCl}(\mathbf{m M})$} & \multicolumn{2}{c|}{ Relative fungicidal activity $(\%)$} \\
\cline { 2 - 3 } & StAP1 & StAP3 \\
\hline 25 & 100 & 100 \\
75 & $98 \cdot 8 \pm 1 \cdot 2$ & 100 \\
150 & $71 \cdot 7 \pm 2 \cdot 2$ & $85 \cdot 5 \pm 1 \cdot 5$ \\
300 & $60 \cdot 0 \pm 1 \cdot 1$ & $62 \cdot 0 \pm 2 \cdot 3$ \\
\hline
\end{tabular}

than F. solani and that StAP1 is a more potent antimicrobial protein than StAP3 for these potato pathogens.

The mechanism of action of antifungal proteins includes fungal cell wall polymer degradation, membrane channel and pore formation, damage to ribosomes, inhibition of DNA synthesis, and inhibition of the cell cycle (Selitrennikoff, 2001; Brogden, 2005). To obtain more information about the mode of action of StAPs as antifungal proteins, we investigated whether StAP1 and StAP3 exert a direct effect on spores and mycelia of $F$. solani and $P$. infestans. Binding experiments performed with FITClabelled StAPs confirmed that both proteins are able to bind to spores and mycelia of $F$. solani and cysts of $P$. infestans in a dose-dependent manner. Using the SYTOX Green assay we were able to show that StAPs cause membrane permeabilization of spores and hyphae of $F$. solani and cysts of $P$. infestans. The patterns of binding and permeabilization observed correlated with the lethal effect of these StAPs on $F$. solani and $P$. infestans spores and cysts, since similar doseresponse curves were observed. The membrane damage curves also showed the same shape as those previously obtained for the growth inhibition of $F$. solani in the presence of StAP1 and StAP3 (Guevara et al., 2002, 2004).

Cation sensitivity has been described for basic antimicrobial proteins, which are thought to act via electrostatic interactions. Moreover, the results obtained here show that antimicrobial activity of StAPs decreases with increasing $\mathrm{NaCl}$ concentration. However, the percentage inhibition by $\mathrm{NaCl}$ is lower than that observed for other antimicrobial proteins and peptides in the same conditions (Bruhn et al., 2003; Theis et al., 2003). This result suggests that the electrostatic interaction between StAPs and negatively charged membrane components and/or specific receptors, described for other antimicrobial proteins (Thevissen et al., 1997; Lehrer et al., 1989), could be the initial step of StAPs' antimicrobial activity mechanism.

Reactive oxygen species (ROS) are known mediators of intracellular signalling cascades. Excessive production of
ROS may, however, lead to oxidative stress, loss of cell function, and ultimately apoptosis or necrosis (Nordberg \& Arner, 2001). Here we have shown that StAPs induce the generation of $\mathrm{H}_{2} \mathrm{O}_{2}$ in fungal spores in a dose-dependent manner; this agrees with the results previously reported for histatin, a cationic peptide from man (Kavanagh \& Dowd, 2004; Patrzykat et al., 2002).

Future characterization of the physico-chemical properties and/or putative receptor or target site will facilitate the understanding of the mechanism of antifungal activity of StAPs.

\section{ACKNOWLEDGEMENTS}

This research was supported by grants from the International Foundation for Science (Stockholm, Sweden) and the Organization for the Prohibition of Chemical Weapons (OPCW), The Hague, Netherlands), Comisión de Investigaciones Científicas (CIC), Universidad Nacional de Mar del Plata, Consejo Nacional de Investigaciones Científicas y Técnicas (CONICET) and Agencia Nacional de Promoción Científica y Tecnológica. J.R.M. is a fellow of CONICET, G.R.D. is an established researcher of CIC and M.G.G. is an established researcher of CONICET.

\section{REFERENCES}

Anson, M. L. (1979). The estimation of pepsin, trypsin, papain and cathepsin with hemoglobin. J Gen Physiol 22, 79-89.

Berrocal-Lobo, M., Segura, A., Moreno, M., López, G., GarcíaOlmedo, F. \& Molina, A. (2002). Snakin-2, an antimicrobial peptide from potato whose gene is locally induced by wounding and responds to pathogen infection. Plant Physiol 128, 951-961.

Broekaert, W. F., Cammue, B. P. A., De Bolle, M. F. C., Thevissen, K., De Samblanx, G. W. \& Osborn, R. W. (1997). Antimicrobial peptides from plants. Crit Rev Plant Sci 16, 297-323.

Brogden, K. A. (2005). Antimicrobial peptides: pore formers or metabolic inhibitors in bacteria. Nature 3, 238-250.

Brogden, K. A., Ackermann, M., McCray, P. B. \& Tack, B. F. (2003). Antimicrobial peptides in animals and their role in host defences. Int J Antimicrob Agents 22, 465-478.

Bruhn, H., Riekens, B., Berninghausen, O. \& Leippe, M. (2003). Amoebapores and NK-lysin, members of a class of structurally distinct antimicrobial and cytolytic peptides from protozoa and mammals: a comparative functional analysis. Biochem J 375, 737-744.

Davies, D. R. (1990). The structure and function of the APs. Annu Rev Biophys Chem 19, 189-215.

De Luca, A. J., Jacks, T. J. \& Broekaert, J. (1999). Fungicidal and binding properties of three plant peptides. Mycopathologia 144, 87-91.

Dixon, R. A., Lamb, C. J., Paiva, N. L. \& Masoud, S. (1996). Improvement of natural defense responses, engineering plants for commercial products and applications. Ann N Y Acad Sci 792, 126-139.

Ganz, T. (2003). Defensins: antimicrobial peptides of innate immunity. Nat Rev Immunol 3, 710-720.

Ge, X., Dietrich, C., Matsuno, M., Li, G., Berg, H. \& Xia, Y. (2005). An Arabidopsis aspartic protease function as an anti-cell-death component in reproduction and embryogenesis. EMBO Rep 6, 282-288.

Guevara, M. G., Oliva, C. R., Machinandiarena, M. \& Daleo, G. R. (1999). Purification and properties of an aspartic protease from 
potato tuber that is inhibited by a basic chitinase. Physiol Plant 106, 164-169.

Guevara, M. G., Daleo, G. R. \& Oliva, C. R. (2001). Purification and characterisation of an aspartic protease from potato leaves. Physiol Plant 112, 321-326.

Guevara, M. G., Oliva, C. R., Huarte, M. \& Daleo, G. R. (2002). An aspartic protease with antimicrobial activity is induced after infection and wounding in intercellular fluids of potato tubers. Eur J Plant Pathol 108, 131-137.

Guevara, M. G., Veríssimo, P., Pires, E., Faro, C. \& Daleo, G. R. (2004). Potato aspartic proteases: induction, antimicrobial activity and substrate specificity. J Plant Pathol 86, 233-238.

Hancock, R. E. W. \& Lehrer, R. (1998). Cationic peptides: a new source of antibiotics. Trends Biotechnol 16, 82-88.

Hejgaard, J., Jacobsen, S., Bjorn, S. E. \& Kragh, K. M. (1992). Antifungal activity of chitin binding PR-4 type proteins from barley grain and stressed leaf. FEBS Lett 307, 389-392.

Kavanagh, K. \& Dowd, S. (2004). Histatins: antimicrobial peptides with therapeutic potential. J Pharm Pharmacol 56, 285-289.

Laemmli, U. K. (1970). Cleavage of structral proteins during the assembly of the head of bacteriophage T4. Nature 227, 680-685.

Leah, R., Tommerup, H., Svendsen, I. \& Mundy, J. (1991). Biochemical and molecular characterization of three barley seed proteins with antifungal properties. J Biol Chem 266, 1564-1573.

Lehrer, R. I. (2004). Primate defensins. Nat Rev Microbiol 2, 727-738. Lehrer, R. I., Barton, A., Daher, K. A., Harwig, S. S., Ganz, T. \& Selsted, M. E. (1989). Interaction of human defensins with Escherichia coli. Mechanism of bactericidal activity. J Clin Invest 84, 553-561.

Levy, O. (2004). Antimicrobial proteins and peptides: anti-infective molecules of mammalian leukocytes. J Leukoc Biol 76, 1-16.

Liu, D., Raghothama, K. G., Hasegawa, P. M. \& Bressan, R. A. (1994). Osmotin overexpression in potato delays development of disease symptoms. Proc Natl Acad Sci U S A 91, 1888-1982.

Mauch, F., Mauch-Mani, B. \& Boller, T. (1988). Antifungal hydrolases in pea tissue II: inhibition of fungal growth by combinations of chitinase and $\beta$-1,3-glucanase. Plant Physiol 88, 936-942.

Mutlu, A. \& Gal, S. (1999). Plant aspartic proteinases: enzymes on the way to a function. Physiol Plant 105, 569-576.

Niderman, T., Genetet, I., Bruyere, T., Gees, R., Stintzi, A., Legrand, M., Fritig, B. \& Mosinger, E. (1995). Pathogenesis-related PR-1 proteins are antifungal. Isolation and characterization of three 14-kilodalton proteins of tomato and of a basic PR-1 of tobacco with inhibitory activity against Phytophthora infestans. Plant Physiol 108, 17-27.

Nordberg, J. \& Arner, E. S. J. (2001). Reactive oxygen species, antioxidants and the mammalian thioredoxin system. Free Radic Biol Med 31, 1287-1312.

Oakley, B. R., Kirsch, D. R. \& Morris, N. R. (1980). A simplified ultrasensitive silver stain for detecting proteins in polyacrylamide gels. Anal Biochem 105, 361-363.
Patrzykat, A., Friedrich, C. L., Zhang, L., Mendoza, V. \& Hancock, R. E. (2002). Sublethal concentrations of pleurocidin-derived antimicrobial peptides inhibit macromolecular synthesis in Escherichia coli. Antimicrob Agents Chemother 46, 605-614.

Raikhel, N. V., Lee, H. I. \& Broekaert, W. F. (1993). Structure and function of chitin-binding proteins. Annu Rev Plant Physiol Plant Mol Biol 44, 591-615.

Rawlings, N. D. \& Barrett, A. J. (1995). Families of aspartic peptidases, and those of unknown catalytic mechanism. Methods Enzymol 248, 105-120.

Segura, A., Moreno, M., Madueño, F., Molina, A. \& Garcia-Olmedo, F. (1999). Snakin-1, a peptide from potato that is active against plant pathogens. Mol Plant Microbe Interact 12, 16-23.

Selitrennikoff, C. P. (2001). Antifungal proteins. Appl Environ Microbiol 67, 2883-2894.

Simões, I. \& Faro, C. (2004). Structure and function of plant aspartic proteinases. Eur J Biochem 271, 2067-2075.

Smith, P. K., Krohn, R. I., Hermanson, G. T. \& 7 other authors (1985). Measurement of protein using bicinchoninic acid. Anal Biochem 150, 76-85.

Terras, F., Schoofs, H., Thevissen, K., Osborn, R. W., Vanderleyden, J., Cammue, B. \& Broekaert, W. F. (1993). Synergistic enhancement of the antifungal activity of wheat and barley thionins by radish and oilseed rape $2 \mathrm{~S}$ albumins and by barley trypsin inhibitors. Plant Physiol 103, 1311-1319.

Theis, T., Wedde, M., Meyer, V. \& Stahl, U. (2003). The antifungal protein from Aspergillus giganteus causes membrane permeabilization. Antimicrob Agents Chemother 47, 588-593.

Thevissen, K., Osborn, R. W., Acland, D. P. \& Broekaert, W. F. (1997). Specific, high affinity binding sites for an antifungal plant defensin on Neurospora crassa hyphae and microsomal membranes. J Biol Chem 272, 32176-32181.

Thevissen, K., Terras, F. R. \& Broekaert, W. F. (1999). Permeabilization of fungal membranes by plant defensin inhibits fungal growth. Appl Environ Microbiol 65, 5451-5458.

Thordal-Christensen, H., Zhang, Z., Wei, Y. \& Collinge, D. B. (1997). Subcellular localization of $\mathrm{H}_{2} \mathrm{O}_{2}$ in plants: $\mathrm{H}_{2} \mathrm{O}_{2}$ accumulation in papillae and hypersensitive response during the barley-powdery mildew interaction. Plan J 11, 1187-1194.

Vigers, A. J., Roberts, W. K. \& Selitrennikoff, C. P. (1991). A new family of plant antifungal proteins. Mol Plant Microbe Interact 4, 315-323.

Vizioli, J. \& Salzet, M. (2002). Antimicrobial peptides from animals: focus on invertebrates. Trends Pharmacol Sci 23, 494-496.

Woloshuk, C. P., Meulenhoff, J. S., Sela-Buurlage, M., van den Elzen, P. J. M. \& Cornelissen, B. J. C. (1991). Pathogen-induced proteins with inhibitory activity toward Phytophthora infestans. Plant Cell 3, 619-628.

Zasloff, M. (2002). Antimicrobial peptides of multicellular organisms. Nature 415, 389-395. 